\title{
Preliminary Business Plan \\ District Heating Company for the City of Handlova, Slovakia
}

Prepared by

Pacific Northwest National Laboratory

Tecogen

EGU

Prepared: April 1994

Printed: June 1996

RECEIVED

OCT 041996

OSTI

\section{AN Global \\ At Studies \\ Program}

Pacific Northwest National Laboratory

Advanced International Studies

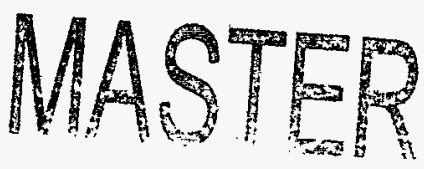

MSTRIBUTION OF THIS DOCUMENT IS UNU dOTIE 


\title{
DISCLAIMER
}

This report was prepared as an account of work sponsored by an agency of the United States Government. Neither the United States Government nor any agency thereof, nor Battelle Memorial Institute, nor any of their employees, makes any warranty, express or implied, or assumes any legal liability or responsibility for the accuracy, completeness, or usefulness of any information, apparatus, product, or process disclosed, or represents that its use would not infringe privately owned rights. Reference herein to any specific commercial product, process, or service by trade name, trademark, manufacturer, or otherwise does not necessarily constitute or imply its endorsement, recommendation, or favoring by the United States Government or any agency thereof, or Battelle Memorial Institute. The views and opinions of authors expressed herein do not necessarily state or reflect those of the United States Government or any agency thereof.

\author{
PACIFIC NORTHWEST NATIONAL LABORATORY \\ operated by \\ BATTELLE \\ for the \\ UNITED STATES DEPARTMENT OF ENERGY \\ under Contract DE-ACO6-76RLO 1830
}




\section{DISCLAIMER}

Portions of this document may be illegible in electronic image products. Images are produced from the best available original document. 
Preliminary Business Plan

District Heating Company

for the City of Handlova, Stovakia

Prepared by

Pacific Northwest National Laboratory

Tecogen

EGU

June 1996

Prepared for the U.S. Department of Energy under Contract DE-AC06-76RLO 1830

Pacific Northwest National Laboratory

Washington, DC 20024 


\section{Disclaimer}

This business plan has been prepared by Pacific Northwest National Laboratory (PNNL) and its subcontractors, Tecogen and EGU (the Slovak Energy Research Institute, Bratislava), using funding provided by the U.S. Agency for International Development's Support for Eastern European Démocracy (SEED) Program.

This information has been compiled with all due care, based in large part on information provided by staff from the City of Handlova; from Slovensky Energeticky Podnik (SEP), who currently manages the heating plant; and from the Ministry of Finance of the Slovakian National Government. All estimates and projections used in this Business Plan contain substantial elements of subjective judgment and analysis. No liability is assumed for the correctness or completeness of the information. Pacific Northwest National Laboratory and its subcontractors disclaim all liability for the possible errors or omissions in this Business Plan or in other written or oral statements communicated or made available to any prospective lender or investor.

This Business Plan may not contain all information necessary for an evaluation by the prospective lender or investor prior to a transaction. For this reason, Pacific Northwest Naxional Laboratory and its subcontractors explicitly assert that neither this Business Plan nor any other information provided by Pacific Northwest National Laboratory or its subcontractors relieves prospective lenders or investors of their duty to undertake their own analysis of the subject business opportunity. 


\section{Summary}

The City of Handlova, Slovakia, needs to replace its district heating system, which is old, unreliable, and expensive to maintain. The current plant is owned by a state-run utility, the Slovensky Energeticky Podnik (SEP). The plan is to privatize the heating plant, acquire capital to rehabilitate the central plant (converting it to a cogeneration facility), install a new hot-water distribution system, and implement an extensive energy efficiency effort in the residential buildings on the system. System capacity is $100 \mathrm{MWt}$, with annual heat sales estimated to be 450,000 gigajoules per year (GJ/yr). The capital necessary for system improvements is estimated to be 465 million Slovakian Krowns (SK) (in 1997 price levels). The total market value of existing fixed assets that will survive the rehabilitation effort as part of the new system is estimated at 342 million SK.

There has been substantial analysis and preparation for this activity, which is documented in demand-side and supply-side technical and economic analyses, an integrated demand/supply report, and this preliminary business plan. The preparation includes investigation of ownership, management, and technology alternatives; estimation of the market value of existing assets and investment requirements; and forecasting of future cash flows. In this last activity, cash flows required to operate the system and pay interest and principal on borrowed money were used as the basis for estimating the price that would have to be charged before the proposed heating plant company would be a viable operation. Given uncertainties in the future inflation rate for this emerging economy, all analyses were done on a real basis with estimated escalation rates for fuel, labor, and other factors of production.

The effort also attempted to document historical costs as a basis for examining whether future cost projections are realistic. This exercise was difficult for several reasons. First, the company has been run under the state government and was never operated as a profit-making enterprise. Second, the Handlova heating plant has been only a small element within the much larger SEP, and it was difficult to identify and segregate the costs and cash flows that are attributable to the Handlova system.

These preliminary projections indicate that the cost of heating from the new system will be reasonable from both a cost per unit of energy basis (SK/GJ) and, from the perspective of an apartment dweller in Handlova, on a total cost per year basis. Delivering heat at the projected cost will, however, require a substantial change in the way that the heating plant is run, with proportionally very large reductions in labor, operations and maintenance (O\&M), and overhead charges. In addition, there will need to be significant revenues from the sale of electricity to the national grid. Some operating savings will naturally occur because of added reliability and efficiency of the new equipment, but beyond this, there will need to be staff reductions and a western-style profit-making orientation. Discussions with system managers indicate that they are prepared to effect this paradigm shift.

This work has been funded through the U.S. Agency for International Development (USAID) through the U.S. Department of Energy (DOE). The effort has been managed by Pacific Northwest National Laboratory (a DOE national laboratory) with significant support from Tecogen (a U.S.-based manufacturer of thermal equipment), and from EGU, the Slovakian National Energy Laboratory. Much 
individual effort and support was required from the officials and citizens of Handlova. Revitalization of the city heating system is a very high priority for Handlova, and the Mayor and his staff have given this effort responsive and effective support. 


\section{Contents}

Executive Summary $\ldots \ldots \ldots \ldots \ldots \ldots \ldots \ldots \ldots \ldots \ldots \ldots \ldots$ iii

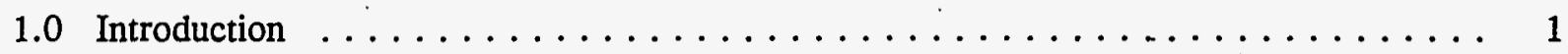

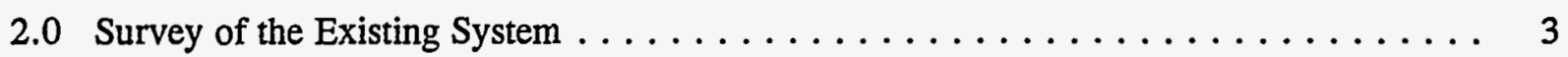

2.1 The Generation and Delivery System $\ldots \ldots \ldots \ldots \ldots \ldots$

2.1.1 System Thermal Balance $\ldots \ldots \ldots \ldots \ldots \ldots \ldots \ldots \ldots \ldots \ldots$

2.1 .2 Fuel Availability $\ldots \ldots \ldots \ldots \ldots \ldots \ldots \ldots \ldots$

2.2 The Energy Consumption System $\ldots \ldots \ldots \ldots \ldots \ldots \ldots \ldots \ldots \ldots \ldots \ldots \ldots$

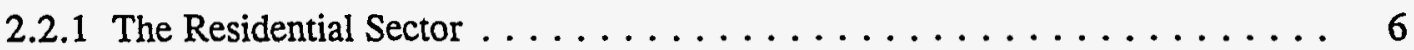

2.2.2 The Non-Residential Sector $\ldots \ldots \ldots \ldots \ldots \ldots \ldots \ldots \ldots$

2.2.3 The Industrial Sector $\ldots \ldots \ldots \ldots \ldots \ldots \ldots \ldots \ldots$

2.3 Forecast for Load Growth $\ldots \ldots \ldots \ldots \ldots \ldots \ldots \ldots \ldots \ldots \ldots \ldots \ldots$

3.0 Description of the Proposed System Upgrade $\ldots \ldots \ldots \ldots \ldots \ldots$

3.1 Demand Side (Efficiency) Plans $\ldots \ldots \ldots \ldots \ldots \ldots \ldots \ldots \ldots \ldots \ldots$

3.2 Preliminary Estimate of Investment Requirements and Schedules . . . . . . . . 13

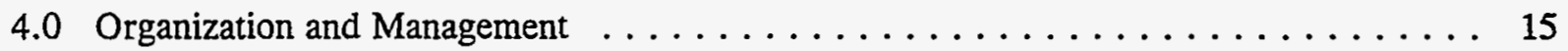

4.1 Organizational Structure $\ldots \ldots \ldots \ldots \ldots \ldots \ldots \ldots \ldots \ldots \ldots \ldots$

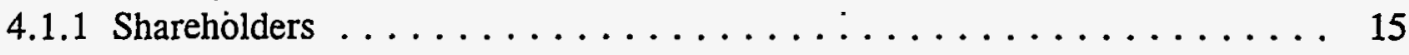

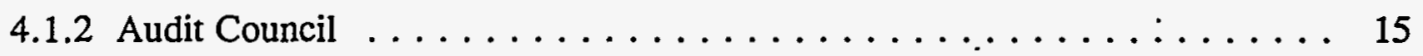

4.1 .3 Board of Directors $\ldots \ldots \ldots \ldots \ldots \ldots \ldots$

4.2 Management Structure and Key Personnel $\ldots \ldots \ldots \ldots \ldots \ldots \ldots$ 
4.3 Relationship to External Parties $\ldots \ldots \ldots \ldots \ldots \ldots \ldots \ldots \ldots \ldots$

4.3.1 Coal, Gas, Water, and Ash Disposal Suppliers . . . . . . . . . . . 17

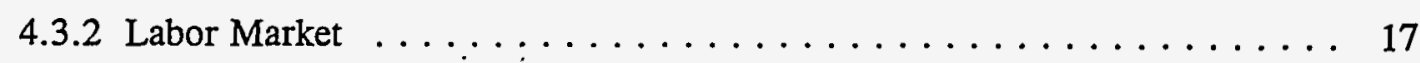

4.3.3 District Heating Customers . . . . . . . . . . . . 18

4.3 .4 Electricity Sales $\ldots \ldots \ldots \ldots \ldots \ldots \ldots \ldots \ldots \ldots \ldots \ldots$

5.0 Regulatory, Legal, and Tax Considerations $\ldots \ldots \ldots \ldots \ldots \ldots$

5.1 Accounting Requirements, Price Controls, and Subsidies . . . . . . . . . 19

5.2 Efficiency and Environmental Requirements . . . . . . . . . . 19

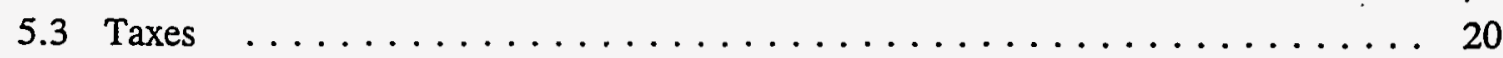

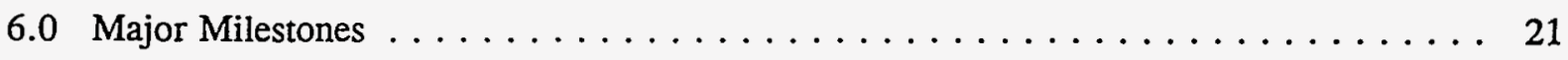

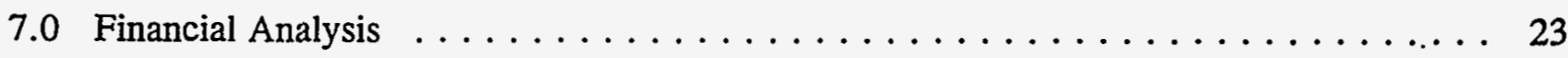

7.1 Historical Financial Information $\ldots \ldots \ldots \ldots \ldots \ldots \ldots \ldots \ldots \ldots$

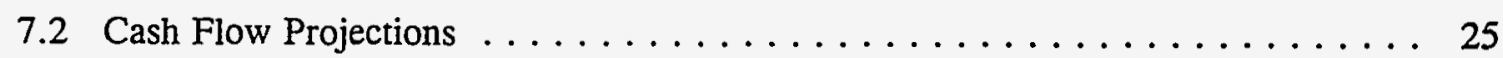

7.3 Correlation of Historical and Projected Cost Streams $\ldots \ldots \ldots \ldots \ldots$

7.4 Heating Plant Fixed Assets $\ldots \ldots \ldots \ldots \ldots \ldots \ldots \ldots \ldots \ldots$

7.4 .1 Buildings and Land $\ldots \ldots \ldots \ldots \ldots \ldots \ldots \ldots \ldots \ldots$

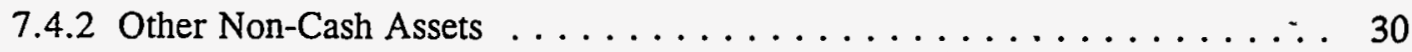

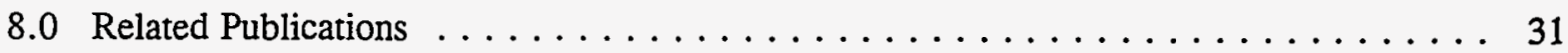




\section{Figures}

2.1 Layout of the Handlova District Heating System $\ldots \ldots \ldots \ldots \ldots$

\section{Tables}

2.1 Heat Balance Summary for Handlova Heating System $\ldots \ldots \ldots \ldots \ldots$

2.2 City Energy Consumption $\ldots \ldots \ldots \ldots \ldots \ldots \ldots \ldots \ldots \ldots \ldots \ldots \ldots \ldots \ldots \ldots$

2.3 Residential Building Thermal Energy Consumption Summary $\ldots \ldots \ldots \ldots \ldots$

2.4 Non-Residential Building Energy Consumption Summary $\ldots \ldots \ldots \ldots \ldots$

2.5 Energy Demand in the Industrial Sector $\ldots \ldots \ldots \ldots \ldots \ldots \ldots$

3.1 Preliminary Estimate of Investment Requirements and Expenditure Schedules . . . . . 13

7.1 Estimated Balance Sheet for Heating Plant as of 31 December $1993 \ldots \ldots \ldots$

7.2 Estimated Statement of Cash Sources and Uses $\ldots \ldots \ldots \ldots \ldots \ldots \ldots$

7.3 Estimated Profit and Loss Statement for the Handlova Heating Plant . . . . . . . . 24

7.4 Cash Flow Forecast: Price Set to Meet Loan Repayments (10-year loan) . . . . . . . 26

7.5 Cash Flow Forecast: Price Set to Meet Loan Repayments (20-year loan) . . . . . . . . 27

7.6 Value of Heating System Buildings and Land $\ldots \ldots \ldots \ldots \ldots$ 


\subsection{Introduction}

As part of the privatization process in Slovakia, the Central Heating System Handlova is being transferred from state to private ownership as a joint stock company. A new private corporation, "Teplaren Handlova A.S." (Heating Plant Handlova), is being established for the purpose of operating the heating system. The new heating company will be managed by professional managers under the direction of new owners as described below:

- $60 \%$ ownership by Slovensky Energeticky Podnik (SEP), the National Electric Transmission Company. SEP currently manages operation of the existing heating plant as a government agency. SEP is soon to be privatized and will be the private majority owner of the new joint stock company.

- $35 \%$ ownership by the City of Handlova. The city currently owns approximately $60 \%$ of the residential buildings the heating plant serves, as well as a significant amount of land through which the distribution system runs.

- 5\% ownership by Sub, Bana Handlova, the Handlova Coal Mine company, which currently provides the fuel for the heating plant.

Recognizing the importance of the district heating system to his citizens, the Mayor of Handlova has taken the lead in restructuring the company, and he will provide continued oversight to ensure that the company is structured as a viable entity that can meet the long-term heating needs of the people.

The existing heating system serves 4,009 of the city's 5,193 dwelling units, providing $72 \%$ of the total residential heat and hot water, $84 \%$ of the thermal energy consumed by the non-residential (commercial) sector, and $100 \%$ of the thermal energy used by the industrial sector. Total end-use consumption is about $450 \mathrm{TJ} / y e a r$, with a peak demand of about $54 \mathrm{MW}_{\mathrm{t}}$, providing an average load factor of $26 \%$.

The existing heating plant is fueled entirely by industrial-grade brown coal dust provided by the Sub Bana Handlova, a coal mine adjacent to the power plant. The proximity of the mine to the plant ensures that an adequate supply of coal will always be available and eliminates the cost of fuel transportation.

The plant is equipped with three boilers that provide a total capacity of 100 tons/hour of steam $(60 \mathrm{MW})$. The balance of plant includes a closed-loop condenser cooling system, a closed-loop coal preparation and delivery system, and mechanical ash collectors. The plant was constructed from 1937 to 1940 as a power plant for the coal mine. In 1965 , construction was begun to convert the system to a district heating system, with service beginning in 1968 . The heat is distributed as steam at $250^{\circ} \mathrm{C}$ and $3.0 / 0.9 \mathrm{MPa}$, through a network consisting of 8,035 meters of pipe $(5,300$ meters buried and 2,735 meters above ground), and 31 heat exchanger stations. The distribution system, including most rights-of-way and most heat exchanger stations, is owned by the City of Handlova.

A large portion of the existing heating plant equipment and the distribution system is at the end of its useful life and will soon have to be replaced, requiring substantial capital investment. Additional - investments need to be made to ensure that emissions from the plant meet Slovakian environmental standards. Under the USAID Support for Eastern European Democracy (SEED) Program, heat supply alternatives and the demand-side energy efficiency potential were investigated by a U.S./Slovak team. 
Results are documented in supply-side, demand-side, and integrated energy resource reports, which are summarized here and are available to the prospective investor. Also available are detailed estimates of the market value of all system assets, and the financial statements of the existing heating company.

On the supply side, three major configurations were investigated as replacement systems: a centralized dual-fuel (coal and gas) cogeneration system; a centralized coal-fired cogeneration system; and a decentralized gas-fired, heat-only system. The demand-side report evaluated the costeffectiveness of numerous energy efficiency options for residential and non-residential buildings, including such measures as insulation, window replacements, hot water flow restrictors, radiator reflectors, improved heating controls, and weather stripping. The integrated report defines the least-cost package of supply-side and demand-side alternatives for upgrading the system.

The combination of a centralized coal-and-gas cogeneration system coupled to an aggressive efficiency program was considered most desirable by the city and has been selected for implementation. This decision was based upon economics, fuel availability, risk reduction, and social and environmental impact upon the community.

To implement required rehabilitation of the central heating system, including the main heating plant, distribution system and the heat exchanger stations, the company seeks-capital investment (debt and/or equity) for its working capital and fixed asset needs. This document is intended to provide potential lenders or investors with essential information adequate for them to make a judgment as to their potential interest in further exploring this opportunity. 


\subsection{Survey of the Existing System}

Figure 2.1 depicts the layout of the Handlova Central Heating System. In general, the central heating system, including the heat generating plant, distribution system, and the heat exchanging stations, is old and inefficient and needs to be replaced.

\subsection{The Generation and Delivery System}

The central heating system covers $80 \%$ of the current energy demand for space heating and water heating in the city of Handlova. The heating plant was built from 1937 to 1940 and was originally designed as a power plant with a condensing steam turbine, which supplied the electricity for the coal mine Handlova. The last major capacity addition to the plant was in 1954, when the boiler K6 ( 45 tons/hour, $432^{\circ} \mathrm{C}, 3.8 \mathrm{MPa}$ ) was built. The power plant was converted to a heating plant in 1965-68 and upgraded with addition of a closed-loop condenser cooling system, natural circulation boilers, a closed-loop coal preparation and delivery system, and mechanical ash collectors.

The steam distribution system was built in 1965 and heat distribution began in 1968. In 1982, because of equipment age and economically ineffective production of electricity, the cogeneration plant was converted to heat production only. Boiler K1 was retrofitted in 1982, and boiler K5 was retrofitted for dual-fuel (coal and natural gas) operation and a pre-combustion reactor in 1990. Boiler K6, which was installed in 1954, was upgraded in 1989 and was converted to dual-fuel operation. Currently the distribution network consists of 31 heat exchanger stations, 5,300 meters of pipes installed in nonaccessible channels, and 2,735 meters of pipes on the surface. Steam is supplied through the non-regulated heat transfer station TG2 at 3.0/0.9 $\mathrm{MPa}$ and $250^{\circ} \mathrm{C}$. Maximum pipe dimension is DN 400 for the steam distribution lines and DN 150 for the condensate return lines.

The heat generating plant uses industrial grade coal (brown powdered coal) with a heating value of $10.5-11.0 \mathrm{MJ} / \mathrm{kg}$ and natural gas with a heating value of $33.4 \mathrm{MJ} / \mathrm{m}^{3}$. Boilers with natural circulation are equipped with closed-loop coal feed and electrostatic filters. Boiler K1 is equipped with a precombustion reactor; boilers $\mathrm{K} 5$ and $\mathrm{K} 6$ are equipped with gas burners with capacity equal to $50 \%$ of the boiler total output. Total output of all boilers is $100 \mathrm{ton} / \mathrm{hr}(60 \mathrm{tMW})$. The plant employs 120 workers and 24 administrative staff members.

The new 115-meter concrete stack was built in 1983; in 1984 and 1985, the flue exhaust system was equipped with electrostatic filters. The old generators have been removed from the building. Ash produced by the heating plant is deposited in a refuse depository outside of the city.

\subsubsection{System Thermal Balance}

The Handlova heating system thermal balance is provided in Table 2.1, with separate breakout for total Handlova heating consumption and that provided by the Handlova district heating system. About $30.7 \%$ of the energy supplied by the district heating system is for space and water heating in the residential sector, with $11 \%$ to $13 \%$ each in the non-residential and industrial sectors. System losses account for almost $45 \%$ of the coal energy provided to the plant. 


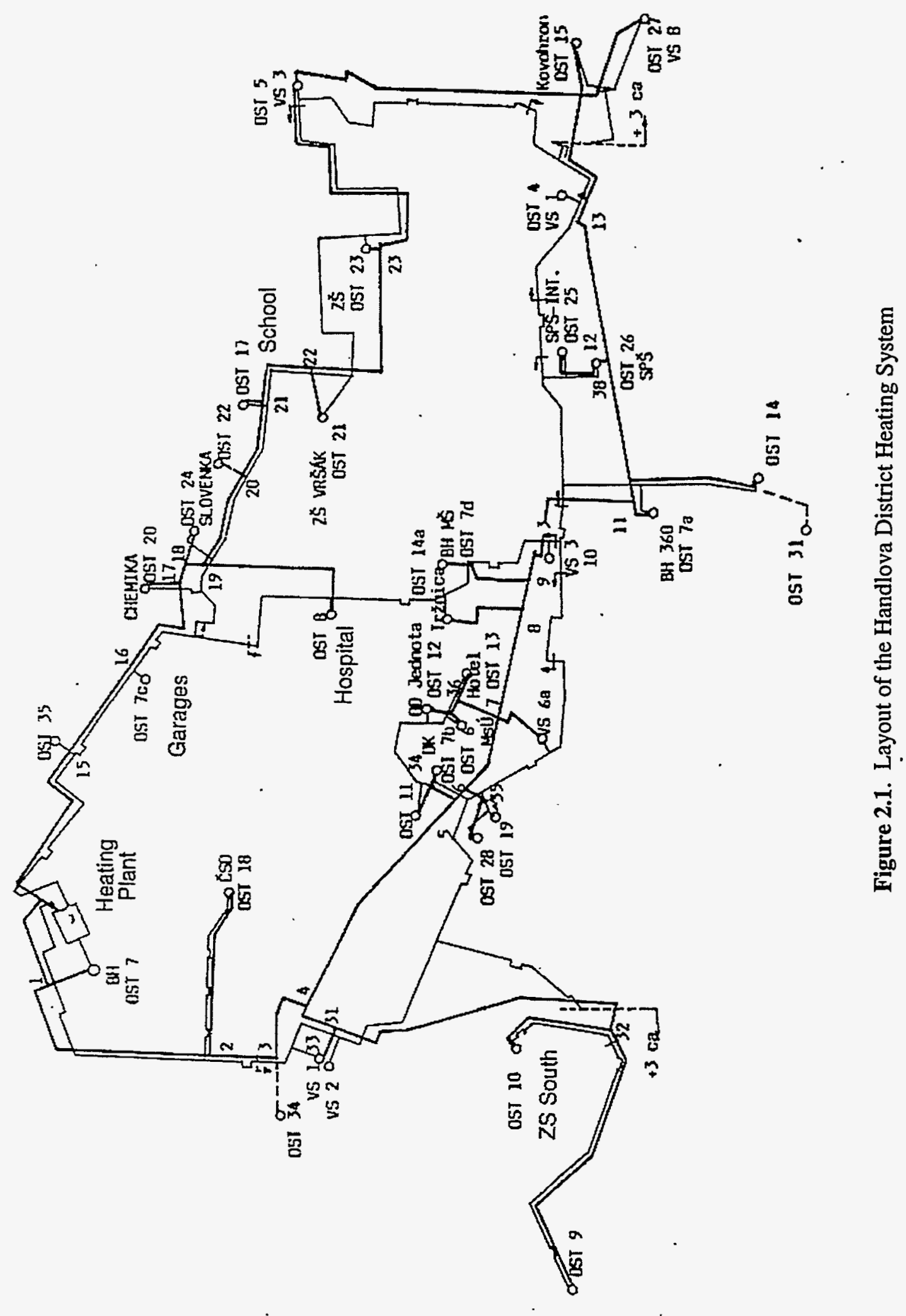


Table 2.1. Heat Balance Summary for Handlova Heating System

\begin{tabular}{|c|c|c|c|c|}
\hline \multirow{2}{*}{$\begin{array}{c}\text { Energy Use Category } \\
\text { Space and Water Heating } \\
\text { Residential } \\
\text { Non-Residential } \\
\text { Industrial }\end{array}$} & \multicolumn{2}{|c|}{$\begin{array}{c}\text { Total Handlova } \\
\text { Consumption (GJ/Year) }\end{array}$} & \multicolumn{2}{|c|}{$\begin{array}{c}\text { System Only District } \\
\text { Heating(GJ/Year) }\end{array}$} \\
\hline & $\begin{array}{l}331,340 \\
107,225 \\
107,671\end{array}$ & $\begin{array}{l}35.5 \% \\
11.5 \% \\
11.5 \%\end{array}$ & $\begin{array}{r}251,033 \\
92,054 \\
107,671\end{array}$ & $\begin{array}{l}30.7 \% \\
11.3 \% \\
13.1 \%\end{array}$ \\
\hline $\begin{array}{l}\text { District Heating Losses } \\
\text { Heating Plant } \\
\text { Distribution System }\end{array}$ & $\begin{array}{r}275,778 \\
91,744\end{array}$ & $\begin{array}{r}29.5 \% \\
9.8 \%\end{array}$ & $\begin{array}{r}275,778 \\
91,774\end{array}$ & $\begin{array}{l}33.7 \% \\
11.2 \%\end{array}$ \\
\hline $\begin{array}{l}\text { Other System Losses } \\
\text { Residential } \\
\text { Non-Residential }\end{array}$ & $\begin{array}{r}17,442 \\
2,380\end{array}$ & $\begin{array}{l}1.9 \% \\
0.3 \%\end{array}$ & $\begin{array}{l}0 \\
0\end{array}$ & - \\
\hline Total: & 933,610 & $100 \%$ & 818,310 & $100 \%$ \\
\hline
\end{tabular}

\subsubsection{Fuel Availability}

The parent company to Sub Bana Handlova, the State Upper Nitra Coal Mines (Hornonitrianske Bane) with headquarters in Prievidza, Slovakia, has, in its letter of August 14, 1993, to SEP Bratislava, guaranteed supply of standard quality coal up to year 2020 . The following coal quality was guaranteed:

$\begin{array}{ll}\text { Heating value } & \mathrm{Qa}=10.5 \mathrm{MJ} / \mathrm{kg} \\ \text { Ash content } & \mathrm{A}=36.38 \% \\ \text { Water } & \mathrm{W}=21.46 \% \\ \text { Sulfur } & \mathrm{S}=1.55 \% \\ \text { Carbon } & \mathrm{C}=66.51 \% \\ \text { Hydrogen } & \mathrm{H}=5.4 \% \\ \text { Nitrogen } & \mathrm{N} .=1.28 \\ \text { Oxygen } & \mathrm{O}=25.49 \%\end{array}$

Handlova is a coal mining community. The coal mine is the largest local employer and has a major impact upon the local social environment. The coal used in the heating plant ( $\sim 70,000$ tons/year) is approximately $16 \%$ of the industrial grade coal from the mine. If it were not used in the Handlova heating plant, it could likely be sold in another market, but at reduced price. Coal is currently sold to the heating plant under annual contracts. In the interest of maintaining a long-term customer, the Handlova Coal Mine is interested in a long-term supply contract with the owners of the new heating plant.

The Slovak Gas Company (Slovensky Plynarensky Podnik), the local gas utility, with headquarters in Prievidza, Slovakia, is able and willing to provide a sufficient gas supply to satisfy the needs of the City of Handlova. Currently, the low-pressure gas distribution network in Handlova is in use and serves only small users (residences). A decentralized heating system would require installation of a new piping system. 


\subsection{The Energy Consumption System}

For the purpose of this study, the city was divided into three energy consumption sectors: residential, non-residential and industrial. These sectors were then further subdivided, and the specific parameters needed to support the energy efficiency analyses were identified. Energy consumption in Handlova for space heating, for water heating, and for industrial processes in 1992 is summarized by fuel type in Table 2.2 .

Table 2.2. City Energy Consumption (GJ/yr)

\begin{tabular}{||c|r|r|r|r|r||}
\hline \multirow{2}{*}{$\begin{array}{c}\text { Energy Use } \\
\text { Category }\end{array}$} & \multicolumn{3}{|c|}{ Sectors } & \multicolumn{2}{c||}{ Total Energy } \\
\cline { 2 - 6 } & Residential & Non-Res. & Industrial & GJ/Year & \multicolumn{1}{|c||}{} \\
\hline \hline Local & & & & & \\
Coal & 29,559 & 0 & 0 & 29,599 & 5 \\
Gas & 66,950 & 50 & 0 & 67,000 & 12 \\
Electricity & 1,200 & 1,684 & 0 & 2,884 & 1 \\
\hline Boiler Houses & & & & & \\
Coal & 0 & 11,080 & 0 & 11,080 & 2 \\
Gas & 0 & 4,737 & 0 & 4,737 & 1 \\
\hline District Heat & 251,033 & 92,054 & 107,671 & 450,758 & 80 \\
\hline Total & 348,782 & 109,605 & 107,671 & 556,058 & 100 \\
& $62 \%$ & $19 \%$ & $19 \%$ & $100 \%$ & \\
\hline
\end{tabular}

\subsubsection{The Residential Sector}

Residential building data were acquired from the Building Management Company in Handlova (Bytovy podnik Mesta Handlova), from the Administration Office of the City Hall, and from AGS Atelier Company which was involved in city development studies. The residential sector was divided into 7 representative residential building types, as follows. Energy use for these buildings is summarized in Table 2.3 .

$\begin{array}{lll}\text { Res-1 } & \text { Apartment buildings } 2 \text { to } 3 \text { floors } & {[1951-1952]} \\ \text { Res-2 } & \text { Apartment buildings } 3 \text { to } 7 \text { floors } & {[1954-1957]} \\ \text { Res-3 } & \text { Pre-fab buildings T 06 B } & {[1968-1984]} \\ \text { Res-4 } & \text { Pre-fab buildings } & {[1962-1965]} \\ \text { Res-5 } & \text { Pre-fab buildings P1-15-NKS } & {[1982-1991]} \\ \text { Res-6 } & \text { Two-family detached houses } & \\ \text { Res-7 } & \text { Single-family detached houses } & \end{array}$

For building types Res-1 through Res-5, the years in which these buildings were constructed is provided in brackets. The data indicate that approximately $27 \%$ of residential heated floor space is in brick-built apartment buildings from the 1950 s (Res 1-2), $49 \%$ in the pre-fab multifamily housing (Res $3-5$ ), and the remaining $24 \%$ in detached single- and two-family houses. 
Table 2.3. Residential Building Thermal Energy Consumption Summary

\begin{tabular}{|c|c|c|c|c|c|}
\hline \multicolumn{6}{|c|}{ Number of Buildings by Energy Source } \\
\hline Building Group & $\begin{array}{c}\text { District } \\
\text { Heat }\end{array}$ & Coal & Gas & Electric & Total \\
\hline $\begin{array}{l}\text { \#1 Apt. Bldg, 2-3 floors } \\
\text { \#2 Apt. Bldg., 3-7 floors } \\
\text { \#3 Pre-Fab Apt. (68-84) } \\
\text { \#4 Pre-Fab Apt. (62-65) } \\
\text { \#5 Pre-Fab Apt. (82-91) } \\
\text { \#6 Duplexes (2 family) } \\
\text { \#7 Single-Family House }\end{array}$ & $\begin{array}{r}0 \\
40 \\
29 \\
10 \\
16 \\
0 \\
0\end{array}$ & $\begin{array}{r}0 \\
1 \\
0 \\
0 \\
0 \\
5 \\
256\end{array}$ & $\begin{array}{r}22 \\
6 \\
0 \\
0 \\
0 \\
128 \\
284\end{array}$ & $\begin{array}{r}0 \\
0 \\
0 \\
0 \\
0 \\
0 \\
20\end{array}$ & $\begin{array}{r}22 \\
47 \\
29 \\
10 \\
16 \\
133 \\
560\end{array}$ \\
\hline Total & 95 & 262 & 440 & 20 & 817 \\
\hline \multicolumn{6}{|c|}{ Number of Apartments by Energy Source } \\
\hline Building Group & $\begin{array}{c}\text { District } \\
\text { Heat }\end{array}$ & Coal & Gas & Electric & Total \\
\hline $\begin{array}{l}\text { \#1 Apt. Bldg., 2-3 floors } \\
\text { \#2 Apt. Bldg., 3-7 floors } \\
\text { \#3 Pre-Fab Apt. (68-84) } \\
\text { \#4 Pre-Fab Apt. (62-65) } \\
\text { \#5 Pre-Fab Apt. (82-91) } \\
\text { \#6 Duplexes (2 family) } \\
\text { \#7 Single-Family House }\end{array}$ & $\begin{array}{r}0 \\
1,198 \\
1,567 \\
376 \\
868 \\
0 \\
0\end{array}$ & $\begin{array}{r}0 \\
12 \\
0 \\
0 \\
0 \\
10 \\
256\end{array}$ & $\begin{array}{r}232 \\
114 \\
0 \\
0 \\
0 \\
256 \\
284\end{array}$ & $\begin{array}{r}0 \\
0 \\
0 \\
0 \\
0 \\
0 \\
20\end{array}$ & $\begin{array}{r}232 \\
1,324 \\
1,567 \\
376 \\
868 \\
266 \\
560\end{array}$ \\
\hline Total & 4,009 & 278 & 886 & 20 & 5,193 \\
\hline \multicolumn{6}{|c|}{ Heated Area by Energy Source $\left(\mathrm{m}^{2}\right)$} \\
\hline Building Group & $\begin{array}{c}\text { District } \\
\text { Heat }\end{array}$ & Coal & Gas & Electric & Total \\
\hline $\begin{array}{l}\text { \#1 Apt. Bldg., 2-3 floors } \\
\text { \#2 Apt. Bldg., 3-7 floors } \\
\text { \#3 Pre-Fab Apt. (68-84) } \\
\text { \#4 Pre-Fab Apt. (62-65) } \\
\text { \#5 Pre-Fab Apt. (82-91) } \\
\text { \#6 Duplexes (2 family) } \\
\text { \#7 Single-Family House }\end{array}$ & $\begin{array}{r}0 \\
70,471 \\
89,719 \\
20,639 \\
54,947 \\
0 \\
0\end{array}$ & $\begin{array}{r}0 \\
632 \\
0 \\
0 \\
0 \\
694 \\
24,421\end{array}$ & $\begin{array}{r}12,517 \\
7,943 \\
0 \\
0 \\
0 \\
18,412 \\
34,069\end{array}$ & $\begin{array}{r}0 \\
0 \\
0 \\
0 \\
0 \\
0 \\
2,511\end{array}$ & $\begin{array}{l}12,517 \\
79,046 \\
89,719 \\
20,639 \\
54,947 \\
19,106 \\
61,001\end{array}$ \\
\hline Total & 235,776 & 25,747 & 72,941 & 2,511 & 336,975 \\
\hline
\end{tabular}




\subsubsection{The Non-Residential Sector}

Non-residential buildings are classified into 7 sectors, as depicted in Table 2.4 below. In general, these buildings were not characterized to the same degree as the residential building stock since resources were limited and each of the non-residential building types represents a very small fraction of the total energy consumption (maximum 3.5\%). All non-residential buildings together represent less than $20 \%$ of total energy consumption.

Table 2.4. Non-Residential Building Energy Consumption Summary

\begin{tabular}{||l|r|r|r|r|r|r|r|r||}
\hline \hline \multirow{2}{*}{$\begin{array}{c}\text { Commercial } \\
\text { Sector }\end{array}$} & \multicolumn{4}{|c|}{ Local } & \multicolumn{1}{c|}{ Boiler House } & District & \multicolumn{2}{c||}{ Total } \\
\cline { 2 - 9 } & Coal & \multicolumn{1}{c|}{ Gas } & Electric & Coal & Gas & \multicolumn{1}{c|}{ Heat } & \multicolumn{1}{c|}{ GJ/yr } & \multicolumn{1}{c|}{$\%$} \\
\hline \hline Education & 0 & 0 & 1,097 & 5,000 & 0 & 45,565 & 51,662 & 47.1 \\
Culture & 0 & 0 & 0 & 0 & 0 & 5,312 & 5,312 & 4.8 \\
Health & 0 & 0 & 200 & 0 & 0 & 19,531 & 19,723 & 18.0 \\
Sports & 0 & 0 & 0 & 6,080 & 0 & 5,850 & 11,930 & 10.9 \\
Office & 0 & 0 & 0 & 0 & 0 & 928 & 928 & 0.8 \\
Service & 0 & 50 & 387 & 0 & 4,737 & 9,687 & 14,861 & 13.7 \\
Hotels & 0 & 0 & 0 & 0 & 0 & 5,181 & 5,181 & 4.7 \\
\hline Total & 0 & 50 & 1,684 & 11,080 & 4,737 & 92,054 & 109,605 & 100 \\
& $0 \%$ & $0.1 \%$ & $15 \%$ & $10.1 \%$ & $4.3 \%$ & $84 \%$ & $100 \%$ & \\
\hline
\end{tabular}

\subsubsection{The Industrial Sector}

The industrial sector in Handlova is represented by the following firms: Coal Mine Handlova including garages, Slovenka, Lahke Universalne Konstrukcie, AMK, Chemika, CSD station and State Agricultural Farm. At each of these sites, thermal energy is used only for space and water heating; industrial use of thermal energy is negligible. Except for the coal mine industry, this energy demand sector is relatively small and was not characterized in detail because of the time and budget limitations of the project (see Table 2.5).

\subsection{Forecast for Load Growth}

The load growth projections for the system are based upon the Urban Development Plan for the City of Handlova. This study, performed by AGS Atelier for the City Hall in 1993, predicted that the city population would increase from 18,332 in 1992 to 19,500 by the year 2010. Extrapolating the growth curve at a conservative rate produces an estimate that the city population will reach 19,750 by 2022. This is a population increase of approximately 1400 people, or $5.22 \%$. Industrial activity in this scenario was assumed to stay at the 1992 level with no increase in thermal energy demand. Under these assumptions, energy demand for space heating and water heating would increase by $18,206 \mathrm{GJ}$, or $3.22 \%$ of 1992 demand levels. The comparable increase in district heating demand is estimated at $11,268 \mathrm{GJ}$, or $4.5 \%$. 
Table 2.5. Energy Demand in the Industrial Sector

\begin{tabular}{||l|r|r|l||}
\hline \multicolumn{1}{|c|}{ Industrial Users } & $\begin{array}{c}\text { Heating } \\
\text { GJ/yr }\end{array}$ & \multicolumn{1}{c|}{$\boldsymbol{\%}$} & \multicolumn{1}{|c|}{ Industry Category } \\
\hline \hline Sub Bana Handlova & 76,736 & 71 & Handlova Coal Min \\
\hline Chemika & 5,684 & 5 & Small chemical plant \\
\hline Lahke Konstrukcie & 19,177 & 18 & Light steel fabrication \\
\hline Slovenka & 2,114 & 2 & Textile factory \\
\hline AMK & 188 & 0 & Automobile repair \\
\hline CSD Station & 2,079 & 2 & Railroad station \\
\hline State Farm & 1,693 & 2 & Farm \\
\hline Total & 107,671 & 100 & \\
\hline
\end{tabular}




\subsection{Description of the Proposed System Upgrade}

The existing central plant will be upgraded to a dual-fuel cogeneration facility, and the existing steam distribution system will be replaced with a modern hot water two-pipe system with pressure independent heat exchanger stations and a central pumping station located at the central heating plant. Under this supply configuration, the winter peak load is supplied by the baseload (coal) steam boilers, which also provide steam to the electrical turbine. This generally occurs when the average ambient air temperature drops below $12^{\circ} \mathrm{C}$, or about 5,200 hours per year, and is estimated to result in approximately $22.4 \mathrm{GWh} /$ year of electricity generation. During the summer peak, the load is supplied only by the gas-fired boilers, and no electricity is produced.

In the central plant, the plan is to have the two existing boilers and hot water manifolds rebuilt, as well as the fuel supply and ash removal equipment. In addition, a new chemical plant will be established for water treatment, and additional equipment procured, including new gas-fired hot water boilers, a $6.2-\mathrm{kV}$ electrical distribution center, a new mechanical room, a new hot water heat exchanger station, and limestone preparation equipment. Finally, a new ash dump site will be prepared. The total cost estimate for the central plant is about 200 million Slovakian Krowns (SK) (1997 price levels). Detailed equipment specifications are provided in the supply-side report.

The system will use pre-insulated pipe that is buried alongside the existing steam distribution system. Construction is expected to take two years (1995 and 1996) with heat exchanger replacements made during the summer period. Preliminary hydraulic and engineering calculations have been completed, and preliminary cost estimates have been made based upon averages of several quotes secured from different manufacturers. The cost for the distribution system is estimated at 73 million SK, with replacement of the heat exchangers estimated at 60 million SK (1997 price levels).

Total capital required for the system is then about 333 million SK (1997 price levels). Operating parameters are summarized below:

$\begin{array}{lrl}\begin{array}{l}\text { Energy Produced } \\ \text { Thermal Energy }\end{array} & 640,320 & \mathrm{GJ} / \text { year } \\ \text { Electricity } & 22,400 & \mathrm{MWh} / \text { year } \\ \text { System Consumption } & & \\ \text { Thermal Energy } & 110,234 & \mathrm{GJ} / \text { year } \\ \text { Distribution Losses } & 26,942 & \mathrm{GJ} / \text { year } \\ \text { Electricity } & 1,790 & \mathrm{MWh} / \text { year } \\ \text { Energy Delivered } & & \\ \text { Hot Water } & 530,050 \mathrm{GJ} / \text { year } \\ \text { Electricity } & 20,610 \mathrm{MWh} / \text { year } \\ \text { Fuel \& Consumables } & & \\ \text { Coal }(10.5 \mathrm{MJ} / \mathrm{kg}) & 69,307 & \text { tons/year } \\ \text { Gas }\left(33.4 \mathrm{MJ} / \mathrm{m}^{3}\right) & 3,947 & 10^{6} \mathrm{~m}^{3} \\ \text { Limestone } & 6,931 & \text { tons/year } \\ \text { Ash Production } & 25,218 & \text { ton } / \text { year }\end{array}$




\subsection{Demand-Side (Efficiency) Plans}

A thorough analysis was made of the space and water heat efficiency measures that are available to minimize the system load and reduce energy costs for Handlova's citizens. The efficiency. measures that were found to be cost-effective were as follows:

- insulate building side walls

- weatherstrip elevator penthouse, stairways, doors, and windows

- weatherstrip doors and windows

- install revolving or double doors in vestibules

- install storm windows

- install zone valves on radiators

- install central thermostats with "on-time" counter in each apartment

- install heat recovery vent system in basements

- install heat reflectors behind each radiator or heater

- remove draperies from radiator

- install low-flow shower heads

- install flow restrictors on faucets

- insulate hot water pipes in unconditioned spaces

- install hot water flow meters

- install waste water heat recovery heat exchangers.

The potential is substantial: up to $20 \%$ of the current residential district heating load could be eliminated by efficiency measures at current fuel prices. Most of this efficiency is found in the large prefabricated apartments (residential building groups 2-5). The total cost of implementation for efficiency in the residences heated by the district heating system is approximately 131 million SK (1997 price levels).

It is expected that full implementation of cost-effective measures will take 5 years or more. The overall plan is to install supply-side capacity that is as small as possible for meeting today's energy demands and then meet any load growth through efficiency measures. This approach has worked very well in the United States and other parts of the world, and we expect it to prove successful here as well. About $60 \%$ of all the buildings that are candidates for efficiency retrofits are owned by the City, and the remaining are owned by building cooperatives. Thus, gaining access for implementation and periodic maintenance should not be a problem. 


\subsection{Preliminary Estimate of Investment Requirements and Schedules}

Table 3.1 is a preliminary estimate of investment requirements and expenditure schedules. All investment requirements are expressed in 1997 price levels.

Table 3.1. Preliminary Estimate of Investment Requirements and Expenditure Schedules

\begin{tabular}{|c|c|c|}
\hline Investment Category & Investment (1000 SK) & $\begin{array}{c}\text { Schedule of } \\
\text { Expenditures }\end{array}$ \\
\hline $\begin{array}{l}\text { Central Plant Upgrade } \\
\text { Distribution System } \\
\text { Heat Exchangers } \\
\text { Efficiency Upgrades }\end{array}$ & $\begin{array}{r}200,414 \\
73,282 \\
59,957 \\
\cdot 131,301\end{array}$ & $\begin{array}{l}1995-1996 \\
1995-1996 \\
1995-1996 \\
1997-2001\end{array}$ \\
\hline Total & 464,954 & \\
\hline
\end{tabular}





\subsection{Organization and Management}

The heating plant and distribution system are currently operated by a staff of highly experienced personnel. The corporation is committed to creating a management structure that will continue to utilize the expertise of these staff and assure sound control of the operations and continuing cooperation between various departments, such as administrative, marketing, engineering, facilities, etc. The company is also making the commitment to support continuing management development of the personnel and to adopt sound environmental and social policies. Management will be responsible to the Board of Directors of the corporation.

\subsection{Organizational Structure}

The proposed joint stock company will be organized according to Slovakian General Business Law 513/1991. Accordingly, the management structure will comprise shareholders, an Audit Council, and a Board of Directors.

\subsubsection{Shareholders}

The joint stockholders will own the company and exercise their management rights through shareholder meetings, which will be held at least annually.

\subsubsection{Audit Council}

The Audit Council is established and operates according to the General Business Law. Its responsibilities and authorities are set by company bylaws developed by the shareholders. Its responsibilities include review of accounting practices and oversight of management implementation of shareholder directives.

\subsubsection{Board of Directors}

The Board of Directors, which directly oversees company management, is elected by the shareholders. At the current time, the plan is to structure the Board as follows:

Chairman: 1 representing ENO (Electric Power Company Novaky)

Members: 1 representing ENO

1 representing the City of Handlova

1 representing the Coal Mine

1 Director of Operations at the heating plant

1 (or more) member(s) representing the financing source(s).

Note that ENO is the subsidiary of SEP that currently manages the heating plant and will provide SEP representation on the privatized company. 


\subsection{Management Structure and Key Personnel}

The existing management structure is effective and will be retained in its current form. Lower levels of management will be developed as appropriate to provide effective customer-oriented service.

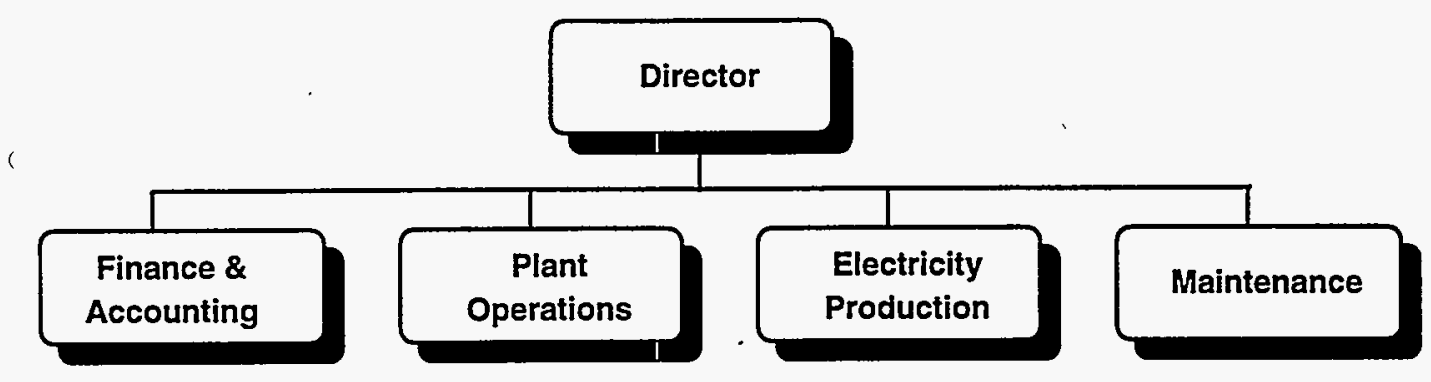

\section{Director of Heating Plant: Mr. Josef Britan}

Mr. Britan holds a Master's degree in Mechanical and Electrical Engineering from the Technical university in Zilina, Slovakia, and attended several courses in management and accounting at the University of Economy in Bratislava. He has 20 plus years of experience in the energy generation business. From 1974 to 1991, he worked in the Electric Power Company Novaky as the maintenance department head (7 years) and as shift director (10 years). In 1991 he was promoted to director of Heating Plant Handlova. Mr. Britan is a seasoned plant manager with excellent managerial and decision-making abilities. He is 46 years old.

\section{Deputy Director for Finance and Accounting: Mrs. Anna Madolova}

Mrs. Madolova holds a BS degree in Economics from the College of Economics, Prievidza, Slovakia, and has completed several courses in accounting, financing, and general economics. She has 39 years of experience in accounting and economics. She has worked in different departments of the Heating Plant Handlova since 1956. Since 1972, she has been head of the plant Department of Finance and Accounting. Mrs. Madolova has a superior knowledge of the plant operation and financial performance, a high level of personal commitment to the company, and an excellent professionalism. She is 54 years old.

\section{Deputy Director for Production: Mr. Tibor Janoska}

Mr. Janoska holds a BS degree in Mechanical Engineering from the Technical School in Handlova, Slovakia, and has completed several technical and management courses organized by Swiss-based educational organization. He has 13 years of experience in technical management of the Heating Plant Handlova. He has proven technical and managerial capability and an excellent ability to manage heat production and distribution. He is 45 years old. 
Mr. Marko holds a BS degree in Electrical Engineering from the Technical School in Handlova, Slovakia, and has completed courses in controls, regulation, and data acquisition technologies. He has 35 years of experience, with 33 in management positions. During his professional life, he worked in several electric power companies as engineer, foreman and shift manager. Since 1991, he has managed the plant electric department. Mr Marko is 56.

\section{Deputy Director for Maintenance: Mr. Dusan Weiss}

Mr. Weiss holds a BS degree from the Technical School in Handlova, Slovakia, and has attended several technical and management courses. He has 26 years of technical and management experience. He has been with the Heating Plant Handlova since 1968, working in several departments. He has managed the maintenance department since 1991. Mr Weiss is 45 .

\subsection{Relationship to External Parties}

\subsubsection{Coal, Gas, Water, and Ash Disposal Suppliers}

The coal necessary for the plant is available from Sub Bana Handlova, the coal mine that sits adjacent to the heating plant. Coal extracted from the mine is transferred directly to the heating plant via conveyor belt. The coal mine has recently undergone a resource assessment which assured that the coal supply will be plentiful well into the 21 st Century. Should coal not be available from the mine for some unforeseeable reason, there are four other coal mines in the Slovak Republic that could supply the plant. Costs would likely rise, however, by about $50 \mathrm{SK} /$ ton, to account for transportation costs. Ceilings for coal tariffs are set by the Ministry of Finance. Individual coal mines are free to negotiate prices lower than the ceiling.

Discussions with Ing. Anton Ondrejkovic, the Technical Director of the coal mine, indicate that the coal mine is eager to cement a long-term relationship with the heating plant. Mr. Ondrejkovic indicated that the coal mine would consider a long-term contract with the heating plant (to replace the current annual contracts), with a significant price reduction possible.

Essentially $100 \%$ of the gas available to the heating plant is foreign, supplied through the Slovak Gas Company, a monopoly supplier. Its gas is provided through a 1994 agreement with Russia, but there are no long-term international guaranteed contracts. However, the dual-fuel cogeneration system will be able to weather any natural gas shortages without affecting heat deliveries.

Surface water supplies are ample for all plant operations. The ash disposal system currently used hy the heating plant is operated by the national government. It has capacity well into the next century and has been approved for operation through the year 2021 .

\subsubsection{Labor Market}

Jobs at the heating plant are considered prized positions among the citizens of Handlova. Managers of the current plant have had no problems identifying and attracting as many capable staff as they have 
required, and they do not expect this situation to change. As indicated above, each of the key management positions is staffed by a qualified professional, and each of these has qualified back-up staff available. The plant maintains a full engineering staff.

\subsubsection{District Heating Customers}

Approximately $62 \%$ of the residential load on the district heating system is in city-owned buildings, with the remaining $38 \%$ owned by individual building cooperatives. The City is willing to commit to minimum heat deliveries.

Each building is metered individually. Heating bills are allocated within each building according to a pre-arranged formula, which provides for $30 \%$ allocation by square footage and $70 \%$ allocation according to readings on radiator evaporative meters. Hot water consumption is generally metered directly in each apartment. Building owners are billed directly by the heating plant and are responsible for paying the bills. The owners, in turn, collect from building residents and apply for appropriate subsidies from the government.

There is a movement among some individual building owners to convert to decentralized gas boilers. This movement is likely to die out when the go-ahead for the new heating system has been given, however, since the delivered cost of heat has been demonstrated to be significantly lower from the district system than from distributed gas boilers. Additionally, the heat supply from the district system will be secure, whereas gas-fired systems may suffer from politically caused supply shortages.

In the past, there have been problems collecting revenues from some building owners, largely because of disagreements on billing practices. These problems are being resolved. In general, collection of revenues should not be a problem because 1) the national government subsidizes the cost of heat to all qualified individuals who are serviced by the district heating system; 2) if an individual cannot pay the costs remaining after the subsidies, a welfare system ensures that bills are paid; and 3) there are laws that allow the heating company to attach bank.accounts of customers. who can pay, but refuse to do so.

\subsubsection{Electricity Sales}

Electricity will be sold to the national grid, which is run by Slovensky Energeticky Podnik (SEP), the majority owner of the proposed joint stock company. The tariffs are set by the Slovak Ministry of Finance. SEP believes that there will be a ready market for electricity generated by the plant. In addition, the Handlova coal mine could serve as a ready market for the entire electricity output of the plant. 


\subsection{Regulatory, Legal, and Tax Considerations}

The Handlova Heating Plant, like the nation in which it resides, is in a state of flux brought about by its rapid privatization. As such, there is some uncertainty concerning relevant legislation and regulation. In order to clarify the situation, a meeting was held with 1) Ing. Frantisek Kubica, Deputy Director of the Department of Manufacturing Industry, Ministry of Economy, Slovak Republic, who is the Chairman of the Branch Committee for Privatization, and 2) Ing. Lubomir Florian, Advisor for Legislation for Privatization, Ministry of Economy, Slovak Republic. The following information was gathered and should help to clarify this uncertainty.

\subsection{Accounting Requirements, Price Controls, and Subsidies}

The price of energy charged to residential customers of a district heating system is regulated by the state government. The Slovak Ministry of Finances, through Public Law 526/1990, as amended by 09/1993 (October 20,1993), imposed the continuation of price control of thermal energy for residential space and water heating for an unspecified transition time period. Under these price controls, unmetered residential customers can be charged a maximum of $137 \mathrm{SK} / \mathrm{m}^{2}$ of heated space annually; metered residences can be charged a maximum of $120 \mathrm{SK} / \mathrm{GJ}$. There are no controls on prices for non-residential (commercial) and industrial use. The government subsidizes the difference between the - cost of delivered heat and its controlled residential price and regulates the level and conditions of subsidy to the users.

The state subsidies for residential space and water heating are based on the difference between the cost of heat and the maximum price allowed by the government. The subsidies are disbursed directly to home owners or to the building management/accounting institution. Owners of single/two-family houses connected to the district heat system are not eligible. Subsidy eligibility is a subject of occupant citizenship and permanent residency, subject to prime residency only, and is subject to minimum efficiency requirements tested by the State Energy Inspection. Eligibility is randomly checked by the Tax Office.

The Ministry also issued mandatory directives "Method and Provisions for Determination of the Price of Thermal Energy by the Thermal Energy Suppliers." This document specifies allowable costs for energy price calculations. In general, these rules are in accord with GATT conventions, and the price can include depreciation of capital, overhead expenses, direct labor, and operation and maintenance costs. Depreciation schedules are specified by Tax Law 286/1992 and generally call for straight-line depreciation over the expected lifetime of the investment.

\subsection{Efficiency and Environmental Requirements}

The heat supplier is required to comply with minimum efficiency standards and is responsible for inspection by the State Energy Inspection. Failure to meet minimum efficiency requirements results in a mandatory $10 \%$ reduction of the maximum allowed price of delivered heat: 


\subsection{Taxes}

The corporation will pay taxes to the State on its taxable income, as defined by Tax Law NR SR $124 / 1993$, and on certain assets such as real estate. (The company will not be subject to any city or local taxes.). An analysis of these taxes indicates that the effective tax rate on taxable income will be approximately 40\%. On December 15, 1993, a new law, established as Amendment \#326/93 to Law 826/92ZB, declared a "tax holiday" of 5 years for any new cogeneration facilities without capacity restriction. The new joint stock company will qualify for this 5-year tax holiday. 


\subsection{Major Milestones}

The overall goal of this plan is to acquire adequate capital investment in the near term to enable the Heating Company to retrofit the heating plant, the distribution system, and the heat exchanger stations by 1997 , when operation of the new system is scheduled to begin. Once the supply and delivery elements have been rehabilitated, the focus will shift to upgrading the demand-side with retrofit of energy systems in the city's building stock. It is expected that this will take approximately 5 years to fully implement. The overall schedule is depicted below.

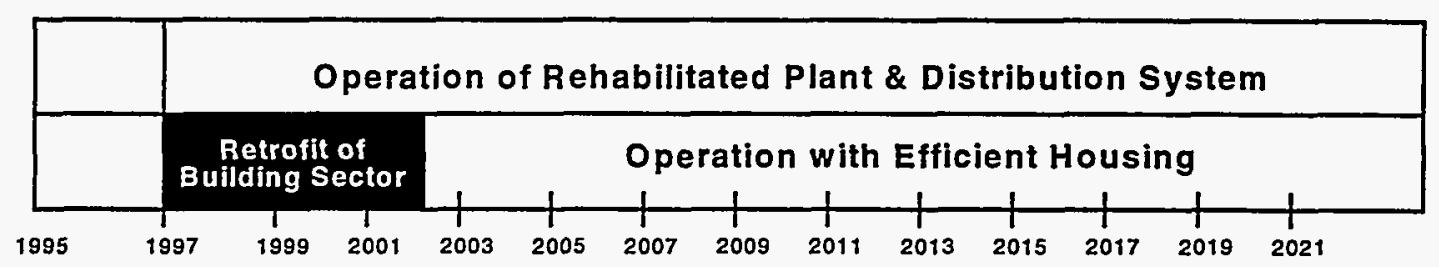

Several near-term requirements are now being addressed:

- Legal separation of the existing heating plant from the larger state-owned Slovensky Energeticky Podnik (SEP) so that it can stand alone as a privately owned joint stock company and enter into negotiations with suppliers, customers, and potential investors.

- Legal establishment of the joint stock company, including allocation of ownership shares among the participating entities; election of officers; development of corporate bylaws; and establishment of the stockholder's committee.

- Closure on a formal long-term contract with the City of Handlova for take-or-pay heat delivery contracts that define minimum quantities of heat that will be purchased by the City Housing Authority. Pursuit of similar contracts' with other residential (apartment cooperatives), commercial, and industrial customers.

- Closure on a long-term coal purchase contract with Sub Bana Handlova, the coal mine, that specifies minimum coal purchases over an extended period in return for guaranteed quantity and prices over the life of the contract.

- Closure on a long-term gas purchase contract that specifies minimum gas purchases over an extended period in return for guaranteed quantity and prices over the life of the contract.

- Closure on a heat delivery metering and information system that is accepted both by the joint stock company. and its customers as a basis for billing and for resolving billing disputes.

- Development of approaches for streamlining management of the new company, with an emphasis upon quality and reduced costs. The management style needs to have a "customer focus," seeking to enhance the reliability of the overall system, as well as an effective trouble-shooting capability to deal effectively and quickly with consumer complaints. 
- Development of a management approach for reducing accounts receivable to "acceptable" levels.

- An effective information dissemination program for the citizens of Handlova that assures them of the viability of the centralized system and the economic benefits of remaining on the district heating system, rather than defecting to distributed gas boilers.

In the meantime, the financial projections presented here are being fine-tuned in accordance with the long-term supply and demand contracts being developed and to reflect improvements in management operations. 


\subsection{Financial Analysis}

The heating plant has been owned and operated as part of the much larger Slovensky Energeticky Podnik (SEP) since its inception in the 1930s. It has not been operated as an independent entity or as a profit-making business; as a result, there are only limited historical data on costs and revenues upon which to develop an understanding of the health of the underlying company. For the purposes of this business plan, SEP has assembled the best data.available for 1993 and formatted them according to GATT standards. The historical costs presented here represent best estimates of Handlova-specific costs as extracted from company-level financial data.

\subsection{Historical Financial Information}

The estimated balance sheet for the heating plant as of 31 December 1993 is shown in Table 7.1.

Table 7.1. Estimated Balance Sheet for Heating Plant as of 31 December 1993

\begin{tabular}{||l|r|l|r|}
\hline \multicolumn{1}{|c|}{ Assets (1000 SK) } & \multicolumn{2}{|c|}{ Equity and Liabilities (1000 SK) } \\
\hline \hline Intangible Assets & 0 & Capital Stock & 59,333 \\
Tangible Fixed Assets & 48,072 & Reserves \& Provisions & -31 \\
Financial Fixed Assets & 0 & Retained Earnings & $-5,858$ \\
Fixed Assets & 48,072 & Equity & 53,444 \\
\hline Cash and Securities & 4 & Long-term Liabilities & 10,690 \\
Accounts Receivable & 33,604 & Short-Term Liabilities & 16,569 \\
Inventories & 4,798 & Total Liabilities & 27,259 \\
Prepayments & $-5,775$ & & \\
Current Assets & 32,631 & & \\
\hline Total Assets & 80,703 & Equity and Liabilities & 80,703 \\
\hline
\end{tabular}

An (estimated) statement of cash sources and uses is provided in Table 7.2.

Table 7.2. Estimated Statement of Cash Sources and Uses

\begin{tabular}{|l|r|r||}
\hline \multicolumn{1}{|c|}{ Cash Flow Elements } & \multicolumn{1}{|c|}{$\begin{array}{c}\text { Uses } \\
\text { (1000 SK) }\end{array}$} & $\begin{array}{r}\text { Sources } \\
(\mathbf{1 0 0 0} \text { SK })\end{array}$ \\
\hline \hline Total Profit/Loss after tax & 5,858 & \\
Depreciation of fixed assets & & 2,918 \\
Increase of pre-payments & & 82 \\
Credits paid to affiliated undertakings & & 14,004 \\
Increased short-term liabilities & & 2,565 \\
Increased long-term liabilities & & 10,608 \\
Capital stock & 4,798 & 59,333 \\
Inventories & 33,604 & \\
Increases in Accounts Payable & & 5,775 \\
Prepayments of accrued income & 50,990 & \\
Adj. value in liquidated tangible assets & 31 & \\
Increase in working funds & 4 & \\
Increase in current accounts & 95,285 & 95,285 \\
\hline Total Cash Flow & & \\
\hline
\end{tabular}


An (estimated) 1993 profit and loss statement for the Handlova heating plant is presented in Table 7.3.

Table 7.3. Estimated Profit and Loss Statement for the Handlova Heating Plant

\begin{tabular}{|c|c|}
\hline Costs & SK \\
\hline $\begin{array}{l}\text { Fuel cost } \\
\text { Material cost } \\
\text { Energy purchases } \\
\text { Repairs and maintenance } \\
\text { Depreciation of property } \\
\text { Other services } \\
\text { Direct labor cost } \\
\text { Miscellaneous labor cost } \\
\text { Labor prepaid } \\
\text { Compulsory social insurance } \\
\text { Retirement } \\
\text { Salary reimbursement } \\
\text { Taxes and fees } \\
\text { Travel expenses } \\
\text { Advertising } \\
\text { Materials sold } \\
\text { Fines and charges } \\
\text { Other operation costs } \\
\text { Interest paid } \\
\text { Losses due to currency exchange } \\
\text { Other financial costs (banking?) } \\
\text { Reserve fund deposits } \\
\text { Cost of technological changes } \\
\text { Inventory discrepancies } \\
\text { Corrections to previous statement } \\
\text { Internal expenses }\end{array}$ & $\begin{array}{r}46,573,972.00 \\
4,460,580.79 \\
8,917,154.91 \\
17,018,172.82 \\
2,918,437.00 \\
1,903,874.05 \\
11,366,900.00 \\
69,558.00 \\
59,232.00 \\
4,934,125.00 \\
225,103.00 \\
1,607,079.00 \\
1,020,948.00 \\
35,007.60 \\
5,083.30 \\
148,968.39 \\
108,498.00 \\
554,681.00 \\
20,177.00 \\
98,050.63 \\
31,897.70 \\
82,419.00 \\
65,994.00 \\
108,115.00 \\
-962,243.00 \\
95,927,282.83\end{array}$ \\
\hline Total Costs & $197,299,068.02$ \\
\hline \multicolumn{2}{|l|}{ Revenues } \\
\hline $\begin{array}{l}\text { Revenues from heat production } \\
\text { Value added tax } 5 \% \text { received } \\
\text { Value added tax } 23 \% \text { received } \\
\text { Value added tax } 23 \% \text { foreign } \\
\text { Revenue from services } \\
\text { Value added tax } 6 \% \text { received } \\
\text { Value added tax } 25 \% \text { received } \\
\text { Value added tax } 25 \% \text { foreign } \\
\text { Internal services } \\
\text { Revenues from materials sold } \\
\text { Other revenues } \\
\text { Other one-time revenues } \\
\text { Total Internal revenues }\end{array}$ & $\begin{array}{r}92,263.313 .00 \\
357,000.00 \\
104,453.00 \\
2,912.00 \\
1,080,345.00 \\
255,000.00 \\
17,520.00 \\
454.00 \\
635,012.00 \\
906,665.00 \\
3,465.00 \\
12.00 \\
95,815,010.00\end{array}$ \\
\hline Total Revenues & $191,441,161.00$ \\
\hline Net Loss & $5,875,097.02$ \\
\hline
\end{tabular}




\subsection{Cash Flow Projections}

Cash flow projections are provided for the proposed joint stock company in the following two tables. These projections are made on a real basis, with general inflation factored out of the analysis. The projections were made using the information provided in the supply and demand reports. The difference between the two tables is that Table 7.4 assumes a 10-year loan for the "supply" capital, whereas Table 7.5 assumes a 20-year loan (which, given available loan terms, may be unlikely, but could be achieved by rolling over a 10-year loan with a balloon payment into a second 10-year loan).

In the cash flow forecasts, the price for heat (SK/GJ) was set on an annual basis so that the cash flows that result would just cover operating costs and loan repayment (principal plus interest). It was assumed that the company would be operated to deliver the lowest possible cost of heat for the citizens of Handlova-hence, there are no earnings to be retained by the company or returned to the stockholders as dividends. These assumptions can easily be modified to simulate other operating models.

The projections assume the following conditions:

- a 5-year tax holiday from $1997-2001$ (tax rate $=0$ ), followed by a $40 \%$ tax on earnings from 2002 through the remaining outyears

- a 10-year (20-year in the second case) loan at a $10 \%$ real interest rate. The loan, which is used to upgrade the central plant and distribution system, is for 333,653,000 SK (1997 price levels). The loan is taken out over the 1995-96 period, and payments start in 1997.

- a series of five 10-year loans to cover building efficiency improvements. The loans are taken out from 1997 through 2001 and total 131,301,000 SK (1997 price levels).

- real escalation rates as follows:

Natural gas

Coal

Electricity (sales)

Labor

Repairs/supplies

General overheads
$2.85 \%$

$2.7 \%$

$6.0 \%$

$4.1 \%$

$3.0 \%$

$3.7 \%$
$1.4 \%$

$2.7 \%$

$6.0 \%$

$2.5 \%$

$2.0 \%$

$2.3 \%$ 
Table 7.4. Cash Flow Forecast: Price Set to Meet Loan Repayments (10-year loan)

Cash Flow Forecast: Price Set to Meet Loan Repayments Handlova Centralized Gas/Coal Cogeneration System with Buildings Efficiency

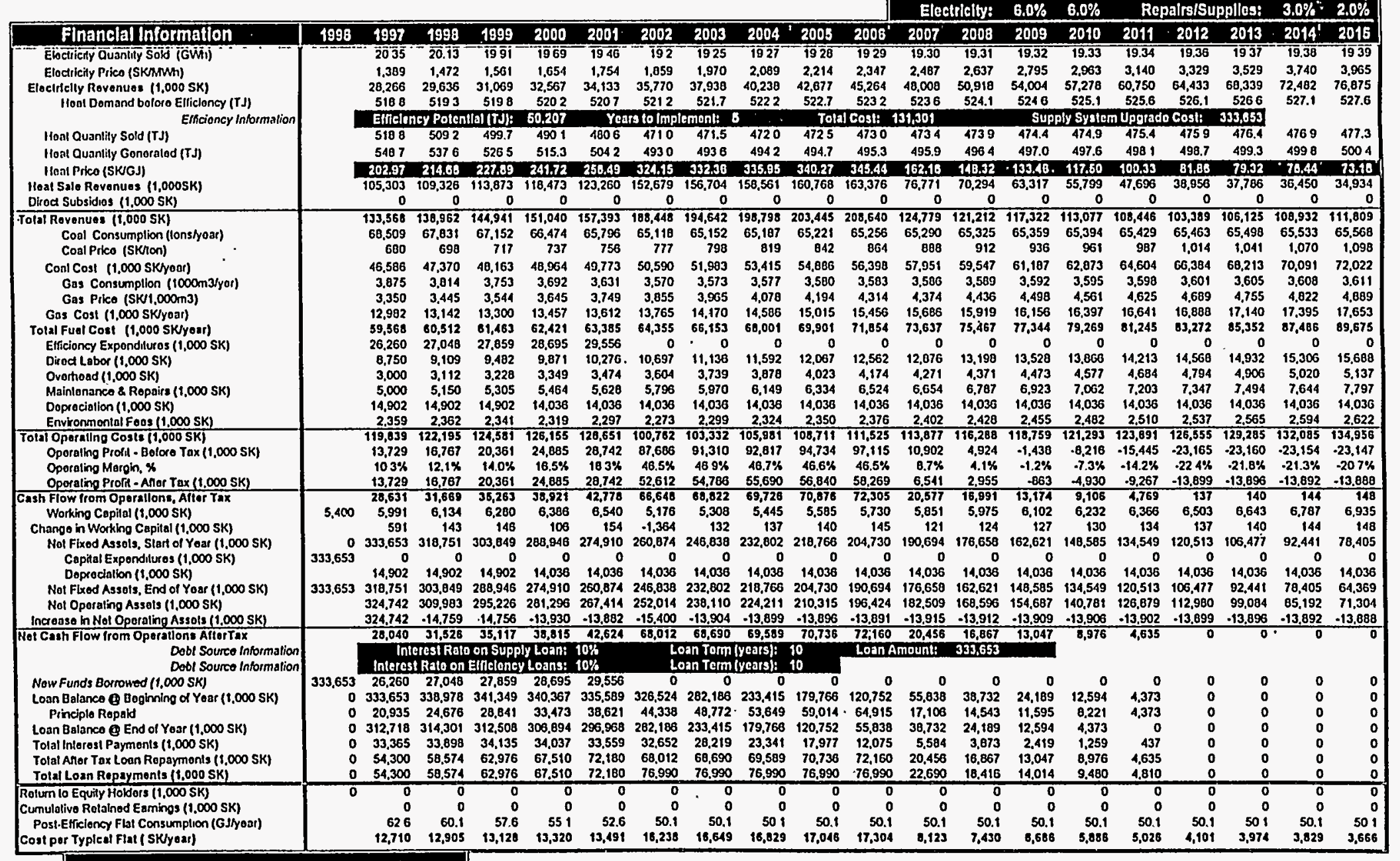

23YoarLovollzed Enargy Cost 235.15 skes 


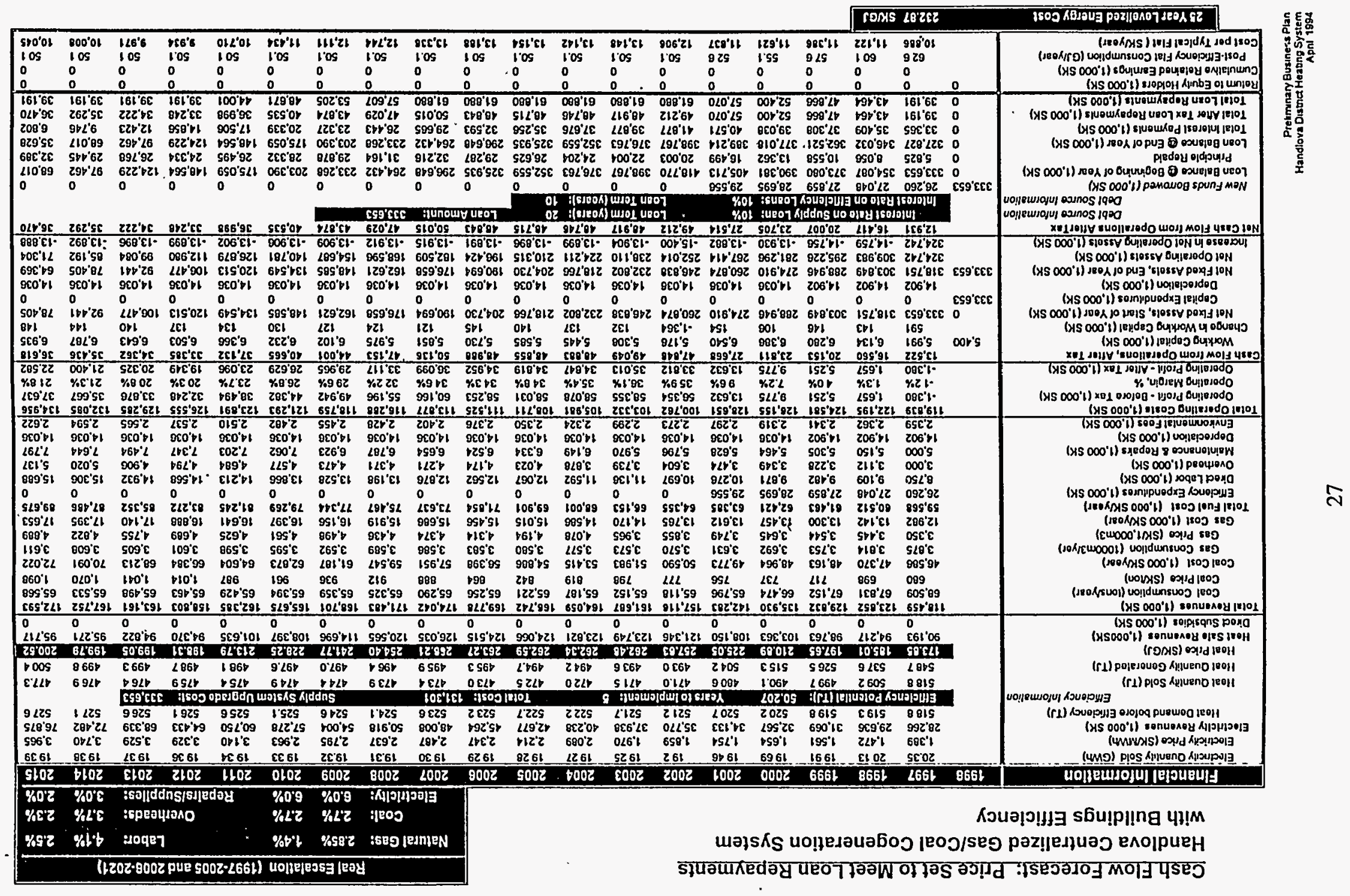

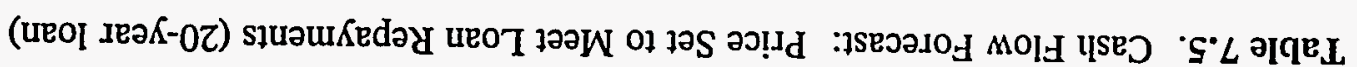


- growth rates as follows:

electricity sales-the assumption is that all electricity generated can be sold. The rate of generation is a function of heat generated by the central system.

heat sales-the population of Handlova is expected to increase by $5.22 \%$ (total) through 2022 . It is assumed that this total increase would be covered by the heating plant. Further, it is assumed that $15 \%$ of the total energy consumption can be eliminated through strategic development of efficiency resources from 1997 through 2001.

Also calculated in the cash flow forecasts is the cost per typical flat (SK/year). This is calculated by taking the current annual energy consumption per Handlova apartment ( 62.6 GJ/year in 1997 and reduced for the next 5 years through efficiency investments) and multiplying by the price of energy. The result is 12,710 SK/year in 1997 (10,886 SK/year for the 20-year loan scenario), which compares favorably with the 10,000-12,000 SK/year expended today by Handlova residents.

A 25-year levelized energy cost was also calculated for the two financing scenarios. For the 10-year supply loan, the levelized cost is estimated to be $235.15 \mathrm{SK} / \mathrm{GJ}$; for the 20-year supply loan, the levelized cost is estimated at $232.87 \mathrm{SK} / \mathrm{GJ}$. Both life-cycle costs are expressed in real terms (without inflation).

\subsection{Correlation of Historical and Projected Cost Streams}

The projected cost streams were developed before actual cost data could be obtained and are based upon best engineering estimates. These estimates were reviewed with management of the existing heating plant and were determined to be feasible. A comparison of projected and historical costs provides the following findings:

- Fuel costs-Engineering estimates of fuel consumption were used as the basis for cost projections. Coal consumption and the overall cost of coal seems reasonable when compared with historical estimates.

- Labor costs-Historical labor costs are approximately 13.0 million SK/year (including social insurance and retirement costs), whereas projected labor costs are about 8.7 million SK for 1997. The assumption is that with a new plant and profit-oriented management, current labor costs can be substantially reduced. Approximately 120 staff are now employed to run the plant, reflecting the inefficient staffing of former state-run operations and the outdated and unreliable nature of the physical plant. Discussions with heating plant staff indicate that this number can and will be reduced to 55 staff.

- Maintenance and repairs-Historical maintenance costs are about 21.4 million SK/year (including labor and materials purchases), compared with 5 million SK/year for the cost projections. This very substantial reduction in costs reflects the change from a physical plant that has reached the end of its life to a new, more efficient system that will be substantially more reliable. 
- Environmental fees-The current environmental fees are about 108,000 SK/year, whereas the projection calls for approximately 2.4 million SK/year to be paid. This is one area where the projections are significantly above current payments.

- General overhead-If all of the remaining costs are considered as "general overhead," the historical costs are about 11.4 million SK/year versus the projected assumption of 3 million SK/year.

Discussions with plant management indicate that a streamlined, efficiently run company can manage with this lower level of overhead costs.

\subsection{Heating Plant Fixed Assets}

A thorough investigation has been made to determine the value of existing fixed assets now owned by the City which will be signed over to the heating plant in return for company stock. The analysis evaluates six main categories of assets

- Buildings

- Land and rights-of-way

- Power-related machinery

- Machine shop equipment and tools

- Special devices and engineering equipment (kilns, lab instruments, etc.)

- Transport means (cranes, conveyors, etc.).

The assessment was done in accordance with the directives provided by the Slovak Ministry of Finance through Edict \#465 (25 October 1991), Edict \#608 (7 December 1992), Ruling \#6/55/1992, and the 10 August 1993 expert standard guideline from the Ministry of Justice. The approach comprehensively identifies all assets and individually values them by two methods, book value and replacement cost (taking into account new cost, age, and current condition). The report is available for inspection. The total market value of these assets is $342,913,000 \mathrm{SK}$, as summarized below.

\subsubsection{Buildings and Land}

The value of heating system buildings and land, according to replacement value, totals $94,498,000$ SK, as detailed below in Table 7.6. 
Table 7.6. Value of Heating System Buildings and Land

\begin{tabular}{|c|c|c|c|c|c|c|c|}
\hline Central Plant Facilities & \multicolumn{2}{|c|}{$\begin{array}{l}\text { Production } \\
\text { Building }\end{array}$} & \multicolumn{2}{|c|}{$\begin{array}{c}\text { Administrative } \\
\text { Building }\end{array}$} & Cableway & \multicolumn{2}{|c|}{$\begin{array}{c}\text { Miscellaneous } \\
\text { Facilities }\end{array}$} \\
\hline $\begin{array}{r}\text { Year Built } \\
\text { Covered Area }\left(\mathrm{m}^{2}\right) \\
\text { Building Value }(1,000 \mathrm{SK})\end{array}$ & \multicolumn{2}{|c|}{$\begin{array}{r}1,953 \\
19,222 \\
32,417\end{array}$} & \multicolumn{2}{|c|}{$\begin{array}{l}1,940 \\
4,939 \\
8,792 \\
\end{array}$} & $\begin{array}{r}1,958 \\
5,700 \\
12,817\end{array}$ & \multicolumn{2}{|c|}{$\begin{array}{r}1959-68 \\
6,369 \\
14,911\end{array}$} \\
\hline \multicolumn{3}{|c|}{$\begin{array}{r}\text { Total Value of Lands: } \\
\text { Total Value of Buildings: } \\
\text { Total Value of Central Plant: }\end{array}$} & \multicolumn{2}{|c|}{$\begin{array}{r}1,729,000 \mathrm{SK} \\
68,939,000 \mathrm{SK} \\
70,688,000 \mathrm{SK} \\
\end{array}$} & & & \\
\hline $\begin{array}{c}\text { Heat Exchanger } \\
\text { Stations } \\
\end{array}$ & ES1 & ES2 & ES3 & ES4 & ES5 & ES7 & ES8 \\
\hline $\begin{array}{r}\text { Year Built } \\
\text { Covered Area }\left(\mathrm{m}^{2}\right) \\
\text { Land Area }\left(\mathrm{m}^{2}\right) \\
\text { Land Value }(1,000 \mathrm{SK}) \\
\text { Building Value }(1,000 \mathrm{SK})\end{array}$ & $\begin{array}{r}1957 \\
207 \\
214 \\
449 \\
1,467\end{array}$ & $\begin{array}{r}1958 \\
157 \\
707 \\
1,484 \\
1,494\end{array}$ & $\begin{array}{r}1965 \\
168 \\
619 \\
1,623 \\
1,762\end{array}$ & $\begin{array}{r}1961 \\
436 \\
592 \\
404 \\
246\end{array}$ & $\begin{array}{r}1975 \\
396 \\
432 \\
295 \\
6,702\end{array}$ & $\begin{array}{r}1984 \\
145 \\
864 \\
888 \\
2,900\end{array}$ & $\begin{array}{r}1989 \\
.183 \\
\mathrm{XXX} \\
\mathrm{XXX} \\
4,115\end{array}$ \\
\hline \multicolumn{3}{|c|}{$\begin{array}{l}\text { Total Value of Lands: } \\
\text { Total Value of Buildings: } \\
\text { Total Value of HX Stations: }\end{array}$} & \multicolumn{2}{|c|}{$\begin{array}{r}5,143,000 \mathrm{SK} \\
18,167,000 \mathrm{SK} \\
23,830,000 \mathrm{SK}\end{array}$} & & & \\
\hline
\end{tabular}

\subsubsection{Other Non-Cash Assets}

The total market value of equipment and machinery has been estimated as follows. The value of rights-of-way is now being determined. No value has been estimated for access to existing markets.

SK

\section{Equipment Category}

$\begin{aligned} 136,650,000 & \text { Power-related machinery } \\ 1,651,000 & \text { Machine shop equipment and tools } \\ 641,000 & \text { Special devices. and engineering equipment (kilns, lab instruments, etc.) } \\ 15,475,000 & \text { Transport means (cranes, conveyors, etc.) } \\ 154,417,000 & \text { Total Value }\end{aligned}$




\subsection{Related Publications}

This report is one of four reports containing an energy assessment of options for upgrading the district heating system of the City of Handlova in the Republic of Slovakia:

Assessment of Supply-Side Alternatives for the Handlova Heating System.

An Assessment of the Building Sector Efficiency Resource for the Town of

Handlova

Integrated Assessment of Supply and Efficiency Resources for the District Heating

System, City of Handlova, Republic of Slovakia.

Preliminary Business Plan - District Heating Company for the City of Handlova, Slovakia

All of these reports were published by

Pacific Northwest National Laboratory

901 D Street S.W., Suite 900

Washington, DC 20024-2115. 